\title{
Gill parasites of Prochilodus lineatus (Valenciennes, 1836) (Pisces; Curimatidae; Prochilodontinae) in the Middle Paraná System (Argentina)
}

Parasitos branquiais em Prochilodus lineatus (Valenciennes, 1836) (Pisces, Curimatidae, Prochilodontinae) no Sistema Paraná Médio (Argentina)

Silvina Beatriz Chemes ${ }^{1}$; Silvia Hebe Gervasoni ${ }^{2 *}$

${ }^{1}$ Departamento Ciencias Naturales, Facultad de Humanidades y Ciencias, Universidad Nacional del Litoral

${ }^{2}$ Departamento de Ciencias Morfológicas, Facultad de Ciencias Veterinarias, Universidad Nacional del Litoral - UNL

Received August 1, 2013

Accepted September 23, 2013

\begin{abstract}
We studied gill parasites of Prochilodus lineatus in the San Javier River, which is connected to the Middle Paraná System (Santa Fe, Argentina). In 25 specimens, the parasite prevalence in branchial organs was $92 \%$ and the average intensity was 8.3 parasites/infested fish. The parasite community showed no dominance of any taxon, but the family Dactylogyridae represented $60 \%$ of the community. We found a significant association between Tereancistrum curimba and Dactylogyridae specimens. The prevalence of the parasites T. toksonum and T. curimba was higher than what has been recorded in the floodplain of the Upper Paraná River, Brazil, demonstrating that the geographic distribution of parasites belonging to Tereancistrum genus is thus expandeing.
\end{abstract}

Keywords: Parasite prevalence, Sábalo, San Javier River, Dactylogyridae, Tereancistrum.

\section{Resumo}

Foram estudados os parasitos das brânquias de Prochilodus lineatus, do rio San Javier, Sistema Paraná Médio (Santa Fe, Argentina). Em 25 espécimes de peixes analisados, a prevalência de parasitos foi de $92 \%$ e a intensidade média de 8,3 parasitos/peixe parasitado. A comunidade parasitária não mostrou predomínio de um taxón, embora tenha sido observado que $60 \%$ da comunidade foi representada pela Família Dactylogyridae. Verificou-se associaçáo significativa entre Tereancistrum curimba e indivíduos da família Dactylogyridae. Os índices de prevalência parasitária de T. toksonum e T. curimba se destacam como sendo superiores aos registrados na planície de inundação do rio Alto Paraná, no Brasil, demonstrando desta maneira expansão da distribuição geográfica de parasitas do gênero Tereancistrum.

Palavras-chave: Prevalência de parasitos, Sábalo, Rio San Javier, Dactylogyridae, Tereancistrum.

\section{Introduction}

The San Javier River is a second-order stream that has a marginal position in the alluvial valley of the Paraná River being a direct receptor of the Chaco-Pampean tributaries. In this section of the alluvial valley, the Cayastá Provincial Reserve extends over an area of approximately 300 ha, limited by the Paso del Tigre stream and the San Javier River, about $80 \mathrm{~km}$ to the north of the city of Santa Fe (ROZZATTI; MOSSO, 1997). Extensive wetlands develop in this area presenting different types of connection with the river bed and their dynamics are closely associated with hydrological fluctuations.

\footnotetext{
*Corresponding author: Silvia Hebe Gervasoni

Departamento de Ciencias Morfológicas, Facultad de Ciencias Veterinarias,

Universidad Nacional del Litoral - UNL, R. P. Luis Kreder 2805, Esperanza

(S3080HOF), Santa Fe, Argentina

e-mail: sgervaso@fcv.unl.edu.ar
}

The species "sábalo", Prochilodus lineatus (Valenciennes, 1836) (Pisces, Curimatidae, Prochilodontinae), inhabits rivers and associated lagoons of the Paraná River-Río de la Plata region in Argentina, Brazil, Paraguay, and Uruguay (LÓPEZ et al., 2003; REIS et al., 2003). It is the most abundant ichthyological resource of the lower Río de la Plata Basin in Argentina, where it also plays a key ecological role. The species abundance can be explained both by its capacity to feed from the organic detritus of sediments (the main source of organic matter in the system) and by its successful reproductive strategy, which is closely adapted to the system's natural regime of flood pulses (ESPINACH ROS; SÁNCHEZ, 2007). Various studies have been carried out on the "sábalos" of this region, including an analysis on their age and growth (CAROZZA; CORDIVIOLA DE YUAN, 1991) and a 
report on their parasites, focusing on the populations of the North Salado River (DE MARCO, 2006).

The aim of the present study was to determine the diversity of gill parasites in P. lineatus in the San Javier River, Middle Paraná System, contributing towards the knowledge of the host-parasite relationship in native species.

\section{Materials and Methods}

Sampling was carried out in a marginal wetland that is directly and permanently connected to the Paso del Tigre stream ( $31^{\circ} 13^{\prime} 32^{\prime \prime} \mathrm{S}$ and $\left.60^{\circ} 10^{\prime} 23^{\prime \prime} \mathrm{W}\right)$, during the low (July and December 2006) and high (May 2007) water phases (Figure 1). Different fishing methods were used to capture the specimens (gillnets with meshes of 50, 70, 80, 105, and $120 \mathrm{~mm}$ openings and drag nets with cod-ends) located in the littoral areas of the lentic environments associated with the San Javier River, in the Cayastá Provincial Reserve (Santa Fe).

The fishes thus obtained were identified, measured and weighed in the field. Then, the whole heads were removed for analysis in the laboratory and were fixed in 10\% formaldehyde. In the laboratory, the opercula were extracted and the branchial arch complex of $P$. lineatus was separated. Each part was thoroughly examined. The branchial filaments were dissected and examined individually. Parasites were removed under a stereoscopic magnifying viewer and were preserved in $70 \%$ alcohol, in order to perform the usual helminthological techniques, including preparation with Hoyer's solution and staining with Gomori's trichrome (EIRAS et al., 2003).

The data recorded were analyzed in accordance with the criteria postulated by Bush et al. (1997) and Rózsa et al. (2000). Total and taxon parasite prevalences and mean intensities were calculated. The existence of dominance in the parasite community was evaluated, and statistical tests ( $\chi^{2}$ and Fisher's association) were applied for subsequent analysis on this.

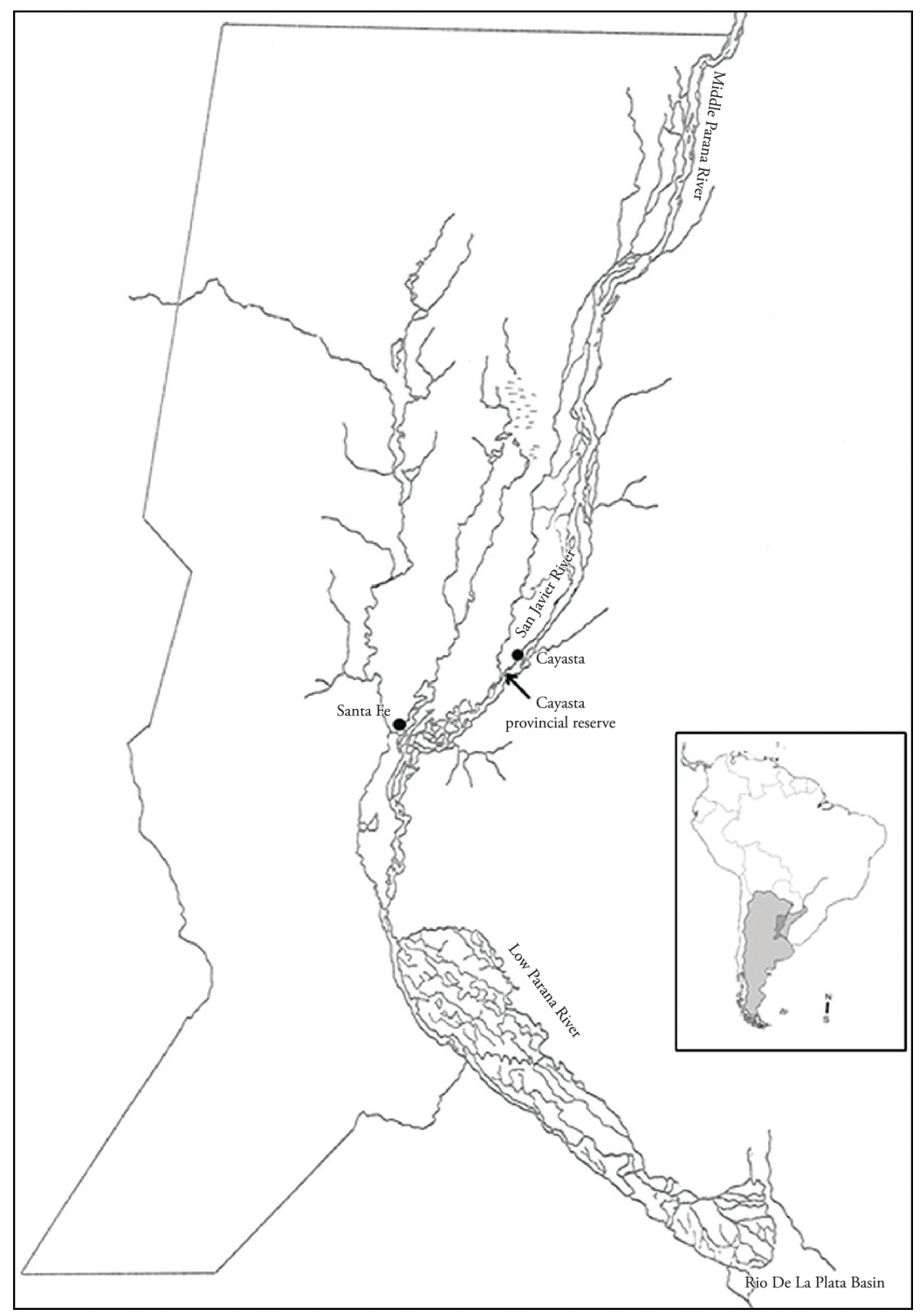

Figure 1. Localization of Cayastá Provincial Reserve, in Middle Paraná System, Santa Fe, Argentina. 


\section{Results and Discussion}

The sample of Prochilodus lineatus was composed of 25 specimens with an average standard length of $27.8 \mathrm{~cm}(20-37 \mathrm{~cm})$ and average

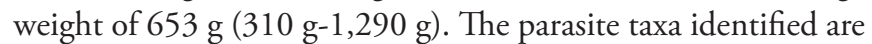
shown in Table 1 and the prevalence, mean intensity, and mean abundance of each taxon are shown in Table 2.

Even though gill ectoparasites may not directly cause the death of hosts, they may affect the energy assignment pattern in many ways, through altering reproduction, respiratory rate and behavior, thus enabling lesion formation and consequently making them more vulnerable, increasing the predation risks (THATCHER, 1991; DOMITROVIC, 1998).

From examination of the branchial organs of $P$. lineatus in the Middle Paraná environment, the total parasite prevalence was found to be $92 \%$. This can be considered to be quite high, since previous studies on juveniles carried out in another river of this basin reached only 23\% (DE MARCO, 2006). Thus, this prevalence reflects the environmental conditions of the study site and is a function of the number of infested hosts; it is also influenced by external factors. Therefore, the encounters between hosts and parasites in their infectious stages, the number of host

Table 1. Taxonomic list of gill ichthyoparasites of Prochilodus lineatus occurring in the Middle Paraná System, Santa Fe, Argentina.

Class Monogenea Carus, 1863
Order Monopisthocotylea Odhner, 1912
Family Dactylogyridae Bychowsky, 1933
Tereancistrum toksonum Lizama, Takemoto and Pavanelli, 2004
Tereancistrum curimba Lizama, Takemoto and Pavanelli, 2004
Dactylogyridae sp.
Family Gyrodactylidae Cobbold, 1885
Gyrodactylidae sp.

Class Trematoda (Rudolphi, 1808)

Subclass Digenea Carus, 1863

Digenea sp.

Phylum Annelida Lamarck, 1809

Class Clitellata Lamarck, 1818

Subclass Euhirudinea Lukin, 1956

Euhirudinea sp.

Phylum Arthropoda Latreille, 1829

Superclass Crustacea Pennant, 1777

Class Maxillopoda Dahl, 1956

Subclass Copepoda Midne-Edwards, 1840

Order Cyclopoida Burmeister, 1834

Family Ergasilidae Von Nordmann, 1832

Ergasilidae sp.

Subclass Branchiura Thorell, 1864

Order Arguloida Yamaguti, 1963

Family Argulidae Leach, 1819

Argulidae sp. species available and other local factors strongly determine each particular situation in relation to the environment (POULIN, 2006). Most of the fish in these lentic environments were caught under low water conditions, which would bring about a higher degree of confinement of these fish; this would explain the higher infestation in cohabiting specimens.

In contrast, the intensity of infestation is determined by processes that are inherent to the fish and the parasite, such as the relative size of infestation site and parasite size, which constitute density-dependent factors that determine a certain tolerance range. Hence, the infestation intensity can be studied as an intrinsic property of the species intervening in each interaction (POULIN, 2006). In the present study, the mean infestation intensity was 8.3 parasites/infected fish, i.e., slightly higher than what was found from studying of the gill ectoparasites of another fish common in these systems, Pimelodus albicans (Valenciennes, 1840) (Pimelodidae), in which the mean infestation intensity was 7.43 (CHEMES et al., 2008).

Most Neotropical monogeneans belong to the family Dactylogyridae, and in general are not highly pathogenic (BOEGER et al., 2006). A wide range of dynamic processes are generated during the interaction between the monogenean and the host fish, been determined by the colonization dynamics of the parasite, the specificity of the host and the immune response of both of them. Monogeneans cause cell hyperplasia and mucus hypersecretion in the host and, at the same time, they have to resist the production of immune responses, in order to ensure their own reproduction. Therefore, the seriousness of pathogenesis caused in the fish is directly proportional to the intensity of parasitism (EIRAS, 1994; BUCHMANN; LINDENSTROM, 2002). In the case of the present data, the mean infestation intensities of Tereancistrum toksonum Lizama, Takemoto and Pavanelli, 2004 and T. curimba Lizama, Takemoto and Pavanelli, 2004, were low. This was concordant with the healthy appearance of the branchial complexes, showing that these ichthyoparasites had little or no pathogenic manifestation on the specimens of $P$. lineatus.

The results demonstrated that the species found are similar to those identified in the alluvial valley of the Upper Paraná River, in Brazil, thus broadening the geographical distribution of Tereancistrum that was described by Lizama et al. (2004).

Table 2. Prevalence, mean intensity, and mean abundance of gill parasite species in Prochilodus lineatus, in the San Javier River, Santa Fe, Argentina.

\begin{tabular}{lccc}
\hline \multicolumn{1}{c}{ Parasite } & $\begin{array}{c}\text { Parasite } \\
\text { prevalence } \\
(\%)\end{array}$ & $\begin{array}{c}\text { Mean } \\
\text { intensity }\end{array}$ & $\begin{array}{c}\text { Mean abun- } \\
\text { dance }\end{array}$ \\
\hline Dactylogyridae sp. & 72 & 4.1 & 2.96 \\
Tereancistrum toksonum & 48 & 2.8 & 1.36 \\
T. curimba & 32 & 2.1 & 0.68 \\
Gyrodactylidae sp. & 8 & 1 & 0.08 \\
Digenea sp. & 8 & 3 & 0.32 \\
Euhirudinea sp. & 12 & 2.4 & 0.48 \\
Ergasilidae sp. & 56 & 2.5 & 1.12 \\
Argulidae sp. & 28 & 0.8 & 0.32 \\
\hline
\end{tabular}


The whole community of ichthyoparasites of $P$. lineatus did not show any dominance of any given taxon $\left(\mathrm{C}_{\text {Simpson }}=0.238\right)$, even though the family Dactylogyridae stood out through representing $60 \%$ of this community. A significant association was found (Fisher $\mathrm{p}=0.0405$ ) between T. curimba and Dactylogryridae specimens, without association with Ergasilidae copepods. This situation had previously been recorded in the alluvial valley of the Upper Paraná River, in Brazil (LIZAMA et al.; 2004, 2005).

In previous reports from Upper Paraná River, there were also observed differences in the parasite prevalence. The values for T. toksonum and T. curimba were notably lower (5.3 and $22.8 \%$ respectively) than in the present study (Table 2) (LIZAMA et al.; 2004, 2005).

The present study provides primary information about the ichthyoparasites of $P$. lineatus in the San Javier River (Middle Paraná System, Río de La Plata basin, Argentina). In this way, it constitutes an initial contribution that subsequently can be expanded by studying the spatial distribution of these parasites in the branchial filaments, as well as the pathological conditions that they generate in their hosts. New data will be necessary for a better comprehension of specific composition of this parasite community, its host-parasite interaction and of its role in the dynamics of these environments.

\section{Acknowledgements}

The authors wish to thank the School of Humanities and Sciences and the School of Veterinary Sciences (UNL), where they carried out their research work; and Dr. R. M. Takemoto (NUPELIA, UEM) for critically reviewing the manuscript. This study was financed by Projects CAI+D UNL 12-120 (2006-2008) and 47-233 (2009-2012), directed by L. M. Rossi.

\section{References}

Boeger WA, Vianna RT, Thatcher VE. Monogenoidea. In: Thatcher VE. Aquatic Biodiversity in Latin America. Sofia-Moscow: Pensoft Publishers, Amazon fish parasites; 2006. v. 1, p. 42-116.

Buchmann K, Lindenstrom T. Interactions between monogenean parasites and theirs fish hosts. Int J Parasitol 2002; 32(3): 309-19. http:// dx.doi.org/10.1016/S0020-7519(01)00332-0

Bush AO, Lafferty KD, Lotz JM, Shostak AW. Parasitology meets ecology on its own terms: Margolis et al. revisited. J Parasitol 1997; 83(4): 575583. PMid:9267395. http://dx.doi.org/10.2307/3284227

Carozza C, Cordiviola de Yuan E. Estudios ictiológicos en la laguna La Cuarentena (Isla Carabajal), río Paraná, Argentina: edad y crecimiento del "sábalo" Prochilodus lineatus Val período 1984-1985 (Pisces, Curimatidae). Revue Hydrobiologie Tropicale 1991; 24(2): 119-129.
Chemes SB, Takemoto RM, Sottini RG. Comunidad de Monogenea en las branquias de Pimelodus albicans (Valenciennes, 1840) en el río Salado del Norte, San Justo (Santa Fe, Argentina). Parasitol Latinoam 2008; 63: 51 57. http://dx.doi.org/10.4067/S0717-77122008000100009

De Marco SA. Estado sanitario de una población de Prochilodus lineatus de ambientes leniticos asociados al río Salado (Santa Fe) [Thesis]. Santa Fe: Universidad Nacional del Litoral; 2006.

Domitrovic HA. Histopatología branquial en Aequidens portalegrensis (Hensel, 1870): II. Lesiones parasitarias. Rev Ictiol 1998; 6(1-2): 43-55.

Eiras JC. Elementos de ictioparasitología. Portugal: Fundação Eng. Antonio de Almeida; 1994.339 p.

Eiras JC, Takemoto RM, Pavanelli GC. Métodos de estudio y técnicas laboratoriales en parasitología de peces. Madrid: Editorial Acribia S.A.; 2003.

Espinach Ros A, Sánchez RP. Proyecto Evaluación del Recurso Sábalo en el Paraná-Informe de los resultados de la primera etapa 2005-2006y medidas de manejo recomendadas. Secretaría de Agricultura, Ganadería, Pesca y Alimentos. Subsecretaría de Pesca y Acuicultura; 2007.

Lizama MA, Takemoto RM, Pavanelli GC. New species of Tereancistrum Kritsky, Thatcher \& Kayton, 1980 (Monogenea: Dactylogyridae: Ancyrocephalinae) from the gills of Prochilodus lineatus (Osteichthyes: Prochilodontidae) from the upper Paraná River floodplain, Brazil. Syst Parasitol 2004; 57(1): 45-49. PMid:14739674. http://dx.doi. org/10.1023/B:SYPA.0000010684.67784.6e

Lizama MA, Takemoto RM, Pavanelli GC. Influence of host sex and age on infracommunities of metazoan parasites of Prochilodus lineatus (Valenciennes, 1836) (Prochilodontidae) of the upper Paraná river floodplain, Brazil. Parasite 2005; 12(4): 299-304. http://dx.doi. org/10.1051/parasite/2005124299

López H, Miquelarena AM, Menni RC. Lista comentada de los peces continentales de la Argentina. Buenos Aires: ProBiota; 2003. Serie Didáctica $n^{\circ} 5$.

Poulin R. Variation in infection parameters among populations within parasite species: Intrinsic properties versus local factors. Int J Parasitol 2006; 36(8): 877-885. PMid:16620823. http://dx.doi. org/10.1016/j.ijpara.2006.02.021

Reis RE, Kullander SO, Ferraris CJ. Check list of the freshwater fishes of South and Central America (CLOFFSCA). Porto Alegre: EdiPUCRS; 2003.

Rózsa L, Reiczigel J, Majaros G. Quantifying parasites in simples of hosts. J Parasitol 2000; 86(2): 228-232. PMid:10780537.

Rozzatti JC, Mosso E. Sistema provincial de áreas naturales protegidas de Santa Fe. Santa Fe: Gobierno de la Provincia de Santa Fe, Administración de Parques Nacionales, Edición de la Cooperadora de la Estación Zoológica Experimental de Santa Fe; 1997.

ThatcherVE. Amazon fish parasites. Amazoniana 1991; 11(3-4): 263-572. 